\title{
PENINGKATAN PRODUKTIVITAS TERNAK KAMBING KACANG PADA KONDISI PEDESAAN DI MALUKU
}

\section{PRODUCTIVITY IMPROVEMENT OF LOCAL GOAT ANIMALS IN RURAL CONDITIONS IN MALUKU}

\author{
G. Joseph \\ Jurusan Peternakan, Fak. Pertanian, Universitas Pattimura, Ambon. \\ e-mail: godliefjoseph@gmail.com

\begin{tabular}{|l|l}
\hline Diterima : 2 Maret 2018 & Disetujui: 22 April 2018
\end{tabular}

\begin{abstract}
Abstrak
Penelitian lapang untuk mengetahui produktivitas ternak kambing lokal (kacang) pada kondisi pedesaan telah dilakukan dengan melibatkan 30 orang peternak sebagai kooperator. Penelitian ini menggunakan 138 ekor ternak kambing kacang berumur 1-1,5 tahun dengan berat rata-rata $12,65 \mathrm{~kg}(10,5-14,8 \mathrm{~kg})$ yang dibagi dalam dua kelompok. Kelompok I: menggunakan 110 ekor ternak kambing terdiri dari 10 ekor jantan dan 100 ekor betina dan ditempatkan dalam kandang individu berbentuk panggung. Pakan yang diberikan berupa hijauan (rumput lapangan + daun waru) dan pakan tambahan yaitu tepung jagung dan tepung ikan teri dengan perbandingan 9:1. Lokasi penelitian adalah di desa Ohoitel dan Ohoitahit. Kelompok II: menggunakan 28 ekor ternak kambing yang terdiri dari 5 ekor jantan dan 23 ekor betina dengan sistem pemeliharaan secara tradisional sebagai kontrol yang berlokasi di desa Wain Baru. Parameter yang diamati yaitu: tingkat kebuntingan (fertilitas), jumlah anak sekelahiran (litter size), berat lahir, pertambahan bobot badan dan tingkat kematian (mortalitas). Hasil pengamatan menunjukkan bahwa jumlah ternak yang bunting (49 dan 5); jumlah anak sekelahiran (1,4 dan 1,0); berat lahir (1,390 dan 857,75 gram), rataan pertambahan berat badan (23,39 dan 19,57 gram/ekor/hari) serta tingkat kematian $(16,36$ dan 17,86) masing-masing untuk kelompok I dan kelompok II.
\end{abstract}

Kata kunci: Ternak Kambing, produktivitas, pedesaan.

\begin{abstract}
Field research to determine the productivity of local goats in the District of Kei Kecil, Southeast Maluku regency was conducted involving 30 farmers as cooperators. This research used 138 head of goats, 1-1.5 years old with an average body weight of $12.65 \mathrm{~kg}$ ( 10.5 to 14.8 $\mathrm{kg}$ ) were divided into two groups. Group I: use of 110 head of goats consisted of 10 males and 100 females and placed in individual cages shaped stage. Given feed forage (grass field + hibiscus leaves) and feed additives of cornmeal and flour anchovy in the ratio 9: 1. The location of research is in the village Ohoitel and village Ohoitahit. Group II: using 28 head of goats consisting of 5 males and 23 females with a traditional maintenance systems as a control located in the village of Wain Baru. Parameters measured were: fertility, litter size, birth weight, body weight gain and mortality. The results showed that the number of pregnant animals (49 and 5); litter size (1.4 and 1.0); birth weight (1.390 and 857.75 grams), the average body weight gain (23.39 and $19.57 \mathrm{~g} /$ head / day) and mortality (16.36 and 17.86) each for group I and group II .
\end{abstract}

Keywords: Productivity, maintenance, goats. 


\section{PENDAHULUAN}

Ternak kambing, tergolong sebagai ternak ruminansia kecil, merupakan jenis ternak yang sangat populer di kalangan petani di Indonesia. Ternak ini lebih mudah dipelihara, dapat memanfaatkan limbah dan hasil ikutan pertanian dan industri, mudah dikembangkan dan pasarnya selalu tersedia setiap saat serta memerlukan modal yang relatif lebih sedikit. Sama halnya dengan ternak lainnya, maka ternak kambing terutama dimanfaatkan untuk produksi daging di samping sebagai penghasil susu dan kulit.

Produktivitas ternak kambing di Indonesia termasuk di Maluku masih sangat rendah, salah satu penyebabnya adalah pakan yang kurang, baik secara kuantitas maupun kualitasnya. Pakan yang diberikan hanya bergantung pada hijauan yang tersedia seperti daun-daunan dan semak dengan sedikit atau tidak ada makanan tambahan/pelengkap (Haryanto dan Djajanegara, 1993).

\section{METODE PENELITIAN}

Penelitian ini menggunakan 138 ekor ternak kambing kacang berumur 1-1,5 tahun dengan berat rata-rata $12,65 \mathrm{~kg}(10,5$ $-14,8 \mathrm{~kg}$ ) terdiri dari 15 ekor ternak jantan dan 123 ekor ternak betina. Ternak kambing ini dibagi kedalam dua sistem pemeliharaan yaitu sistem pemeliharaan secara intensif (Kelompok I) dan sistem
Potensi ternak kambing di Maluku cukup baik, bahkan salah satu jenis ternak kambing yaitu kambing Lakor, telah ditetapkan sebagai ternak asli lokal daerah Maluku selain domba Kisar dan kerbau Moa. Umumnya usaha ternak kambing ini masih dilakukan secara tradisional dan masih merupakan usaha sambilan (Chaniago, 1993). Keadaan ini mengakibatkan rendahnya tingkat produksi dan reproduksi ternak kambing serta tingkat pendapatan petani bila dibandingkan dengan potensi sumberdaya alam yang ada.

Tujuan penelitian ini adalah untuk mengetahui pengaruh sistem pemeliharaan terhadap produktivitas ternak kambing lokal (kacang) yang diberi pakan tambahan pada kondisi pedesaan. Hasil penelitian ini diharapkan dapat memberikan manfaat bagi para peternak dan instansi terkait dalam menentukan kebijakan yang ada hubungannya dengan usaha peternakan kambing di Maluku.

pemeliharaan secara semi intensif (Kelompok II). Kelompok I: menggunakan 110 ekor ternak kambing terdiri dari 10 ekor ternak jantan dan 100 ekor ternak betina. Pakan yang diberikan berupa hijauan (rumput lapangan + daun waru) dan pakan tambahan yaitu tepung jagung dan tepung ikan teri dengan 
perbandingan 9:1 sebanyak 200 g/ekor/hari.

Komposisi kimia dari pakan ternak kambing yang diberikan dapat dilihat pada tabel 1. Lokasi penelitian adalah di desa Ohoitel dan Ohoitahit. Kelompok II: menggunakan 28 ekor ternak kambing yang terdiri dari 5 ekor ternak jantan dan 23 ekor ternak betina dengan sistem pemeliharaan secara tradisional sebagai kontrol yang berlokasi di desa Wain Baru.

Tabel 1. Komposisi kimia pakan ternak kambing.

\begin{tabular}{|l|l|l|l|l|l|l|}
\hline Jenis Pakan Ternak & $\begin{array}{l}\text { Bahan } \\
\text { Kering }\end{array}$ & $\begin{array}{l}\text { Protein } \\
\text { Kasar }\end{array}$ & Lemak & Abu & $\begin{array}{l}\text { Serat } \\
\text { Kasar }\end{array}$ & BETN \\
\hline Daun Waru & 89,71 & 3,19 & 5,03 & 3,47 & 23,0 & 55,02 \\
Pakan Tambahan & 95,92 & 12,64 & 4,0 & 2,95 & 4,65 & 71,64 \\
\hline
\end{tabular}

Sumber: Data Primer.

Penelitian ini bersifat penelitian lapang dengan menggunakan metode action research dan dilakukan dengan pendekatan kemitraan/partisipatory antara peneliti, peternak, penyuluh dan instansi terkait. Metode yang digunakan dalam penelitian ini adalah deskriptif yaitu untuk

\section{Pengumpulan dan Analisis Data}

Data dikumpulkan secara berkala dan untuk mengetahui produktivitas ternak kambing yang dipelihara secara intensif (kelompok I) dan yang dipelihara secara tradisional (kelompok II) dilakukan analisis secara diskriptif. Disamping itu dilakukan

\section{HASIL DAN PEMBAHASAN}

\section{Pola Usahatani Ternak Kambing di Kecamatan Kei Kecil.}

Salah satu tujuan pembangunan peternakan di Maluku adalah peningkatan pendapatan peternak melalui pembinaan kemampuan produksi, penggunaan teknologi maju dan efisien. Tujuan ini akan cepat tercapai bilamana masyarakat peternak melakukan perubahan pola pikir, sikap dan tindakan membandingkan dua sistem pemeliharaan ternak kambing di pedesaan, Khususnya di Keamatan Kei Kecil. Parameter yang diamati yaitu: tingkat kebuntingan (fertilitas), jumlah anak sekelahiran (litter size), berat lahir dan pertambahan bobot badan dan tingkat kematian (mortalitas wawancara langsung dengan peternak dan pengamatan di lapangan untuk mengumpulkan informasi yang relevan dengan kegiatan usaha peternakan kambing di Kabupaten Maluku Tenggara dari budaya tradisional manjadi budaya industri. Usaha peternakan kambing di Indonesia termasuk di Maluku umumnya masih merupakan usaha peternakan rakyat dan bersifat sambilan.

Hasil pengamatan menunjukkan bahwa pola usahatani ternak kambing yang 
dilakukan di Kei Kecil masih bersifat tradisional dan belum memanfaatkan teknlogi yang tersedia. Ternak kambing diikat dengan tali sepanjang 2-3 meter dan ditambatkan pada sebuah patok/ tiang selama beberapa hari di lokasi yang sama. Pakan ternak kambing hanya mengandalkan rumput lapangan yang ada di sekitar tanpa penambahan pakan konsentrat. Konsekuensinya ternak kambing yang dipelihara mempunyai produktivitas yang rendah karena persyaratan minimum yang harus diterapkan dalam usaha budidaya ternak kambing tidak terpenuhi.

Hasil pengamatan dan wawancara langsung dengan para peternak kambing di desa Ohitahit, Ohitel dan Wain Baru Kceamatan Kei Kecil, menyimpulkan bahwa tingkat kematian ternak kambing juga sangat tinggi yaitu sekitar $80 \%$. Hal ini terlihat dari jumlah ternak yang masih hidup hanya 147 ekor dari 675 ekor ternak kambing yang disebarkan selama kurun waktu \pm 8 bulan.

\section{Pengaruh Sistem Pemeliharaan Terhadap Produktivitas Ternak Kambing.}

Hasil penelitian tentang produktivitas ternak kambing yang direfleksikan dengan tingkat kebuntingan (fertilitas), jumlah anak sekelahiran (litter size), berat lahir, pertambahan berat badan dan tingkat kematian (mortalitas) pada kedua sistem pemeliharaan dapat dilihat pada tabel 2 .

Tabel. 2. Produktivitas Ternak Kambing yang dipelihara secara intensif dan semi intensif di Kecamatan Kei Kecil.

\begin{tabular}{|l|c|c|}
\hline \multicolumn{1}{|c|}{ Produktivitas } & $\begin{array}{c}\text { Sistem Pemeliharaan } \\
\text { Secara intensif }\end{array}$ & $\begin{array}{c}\text { Sistem } \\
\text { Pemeliharaan } \\
\text { Secara semi } \\
\text { intensif }\end{array}$ \\
\hline Tingkat Kebuntingan/fertilitas (ekor) & 49 & 5 \\
Jumlah anak sekelahiran/litter size (ekor) & 1,4 & 1 \\
Berat lahir (gram) & 1.390 & 857,75 \\
Pertambahan berat badan (gram/ekor/hari) & 23,39 & 19,57 \\
Tingkat kematian/mortalitas (\%) & 16,36 & 17,86 \\
\hline
\end{tabular}

Sumber: Data Primer.

Hasil penelitian menunjukkan bahwa produktivitas ternak kambing yang dipelihara secara intensif memberikan gambaran yang lebih baik dari pada produktivitas ternak kambing yang dipelihara secara semi intensif. Hal ini diduga karena ternak kambing yang dipelihara secara intensif memperoleh pakan yang cukup baik kuantitas maupun kualitasnya, sebaliknya ternak kambing yang dipelihara secara semi intensif memperoleh pakan yang kurang baik secara kuantitatif maupun kualitatif. Davendra (1993) menyatakan bahwa penyebab utama 
rendahnya produktivitas ternak di negaranegara tropis termasuk Indonesia adalah nutrisi yang kurang baik. Menurut Simatupang (2004) bahwa sebagai negara kepulauan, Indonesia kurang mempunyai keunggulan komparatif untuk

\section{KESIMPULAN DAN SARAN}

\section{Kesimpulan:}

Produktivitas ternak kambing yang dipelihara secara intensif dengan pemberian

\section{Saran:}

Program pembinaan dan pengawasan bagi para peternakan kambing di pedesaan perlu dikembangkan dengan program-program yang lebih

\section{DAFTAR PUSTAKA}

Anderson, L.L. and R.M. Melampy. 1972. Faktor affecting ovulation rate in the pig. In: D.J.A. Cole. Ed. Pig Production. Butterworth and Co. London.

Chaniago, T.D. 1993. Sistem Menejemen (Pengelolaan) Dewasa ini. Dalam: Produksi Kambing dan Domba di Indonesia. Eds. Manica WodzickaTomaszewska, I Made Mastika, Andi Djajanegara, Susan Gardiner dan Tantan R. Wiradarya. Sebelas Maret University Press.

Davendra, C. 1993. Ternak Kambing. Dalam: Pengantar Peternakan di Daerah Tropis. Eds. G. Williamson dan W.J.A. Payne. Gajah Mada University Press.

Haryanto, B. Dan A. Djajanegara. 1993. Pemenuhan kebutuhan zat-zat mengembangkan ternak berbasis pakan rumput. Hal ini disebabkan karena lahan yang digunakan untuk menanam rumput atau hijauan makanan ternak sangat terbatas.

pakan tambahan tepung jagung dan tepung ikan teri di Kecamatan Kei Kecil meningkatkan produktivitasnya.

disempurnakan untuk meningkatkan usaha peternakan rakyat menuju industri peternakan rakyat.

makanan ternak ruminansia kecil. Dalam: Produksi Kambing dan Domba di Indonesia. Eds. Manica Wodzicka-Tomaszewska, I Made Mastika, Andi Djajanegara, Susan Gardiner dan Tantan R. Wiradarya. Sebelas Maret University Press.

Joseph, G., I. Wahyuni, H.T. Uhi dan A. Parakkasi. 2003. Pengaruh tingkat energi terhadap efisiensi reproduksi tikus putih (Rattus norvegicus). Laporan Penelitian. Laboratorium Nutrisi Ternak Daging dan Kerja, Fakultas Peternakan, IPB. Bogor.

Parakkasi, A. 1995. Ilmu Nutrisi dan Makanan Ternak Ruminansia. UI Press.

Stür, W.W. dan P.M. Horne. 2001. Mengembangkan teknologi hijauan makanan ternak (HMT) bersama 
petani kecil. Cara menanam, mengelola dan memanfaatkan HMT. Monograf ACIAR 90. Canberra, Australia.

Sutama, I.K., I.G. Putu dan Manica Wodzicka-Tomaszewska. 1993. Peningkatan Produktivitas Ternak
Rumiinansia Kecil melalui sifat reproduksi yang lebih efisien. Dalam: Produksi Kambing dan Domba di Indonesia. Eds. Manica WodzickaTomaszewska, I Made Mastika, Andi Djajanegara, Susan Gardiner dan Tantan R. Wiradarya. Sebelas Maret University Press. 